\title{
Measurement of Tooth Brushing Frequency, Time of Day and Duration of Adults and Children in Jakarta, Indonesia
}

\author{
Anton Rahardjo ${ }^{1}$, Diah A. Maharani ${ }^{1}$, Bramma Kiswanjaya ${ }^{2}$, Erik Idrus ${ }^{3}$, Julie Nicholson ${ }^{4}$, \\ Paul J. Cunningham ${ }^{4}$, Fred Schäfer ${ }^{4}$ \\ ${ }^{1}$ Department Preventive and Public Health Dentistry, Faculty of Dentistry, Universitas Indonesia, Jakarta 10430, \\ Indonesia \\ ${ }^{2}$ Department of Dentomaxillofacial Radiology, Faculty of Dentistry, Universitas Indonesia, Jakarta 10430, Indonesia \\ ${ }^{3}$ Department of Oral Biology, Faculty of Dentistry, Universitas Indonesia, Jakarta 10430, Indonesia \\ ${ }^{4}$ Unilever R\&D Port Sunlight, Quarry Road East, Bebington, CH63 3JW, UK \\ Correspondinge-mail to: diah.ayu64@ui.ac.id
}

\begin{abstract}
Epidemiological study of tooth brushing is essential to evaluate dental health of a country. Objective: To obtain data on tooth brushing frequency, time of day and duration from adults and children in Jakarta, Indonesia. Methods: Toothbrushes containing data loggers were distributed to 120 random families in Jakarta to record how many times a day, when and for how long subjects brushed their teeth. The families were each composed of a mother, father and two children aged between 6 and 15 years. Results: The mean brushing frequency of the population was 1.27 times per day. The majority of the tooth brushing $(46 \%)$ was performed in the morning. The mean tooth brushing duration of this population was 57.29 seconds. The mothers' tooth brushing frequencies tended to be higher than that of the other family members, and the fathers tended to brush their teeth longer. Conclusion: Effective education aimed at increasing both the duration and frequency of tooth brushing from once to twice per day is urgently required in Indonesia.
\end{abstract}

\begin{abstract}
ABSTRAK
Pengukuran frekuensi, waktu dan lamanya sikat gigi pada populasi dewasa dan anak di Jakarta, Indonesia. Studi Epidemiologi sangatlah penting untuk mengevaluasi kesehatan gigi dan mulut suatu negara. Tujuan: Mendapatkan data frekuensi, waktu, dan lamanya menyikat gigi orang dewasa dan anak-anak di Jakarta, Indonesia. Metode: Sikat gigi yang telah berisi pencatat data dijital disebar secara acak pada 120 keluarga di Jakarta untuk mendapatkan data menyikat gigi dalam keluarga tersebut. Keluarga yang dianalisis adalah bapak, ibu dan dua orang anak yang berusia antara 6 - 15 tahun. Hasil: Rerata frekuensi sikat gigi populasi penelitian adalah $1.27 \mathrm{kali}$ per hari. Sebagian besar individu (46\%) menyikat gigi pada pagi hari. Rerata waktu lamanya menyikat gigi adalah 57.29 detik. Frekuensi menyikat gigi ibu cenderung lebih tinggi daripada anggota keluarga yang lain, sementara bapak cenderung menyikat gigi lebih lama. Simpulan: Pendidikan efektif yang bertujuan untuk meningkatkan lamanya dan frekuensi menyikat gigi dari satu kali menjadi dua kali masih sangat penting dilakukan di Indonesia.
\end{abstract}

Key words: tooth brushing, behavior, Indonesia

\section{INTRODUCTION}

Dental health problems in Indonesia might be the result of a complex interrelation of factors. Socioeconomic disparity has created an imbalance in accessing dental care. ${ }^{1}$ Recent reports have also described the high, unmet demand for and persistent inequality in dental care in Indonesia due to the dental work force shortage, as well as geographical and economic barriers. ${ }^{2} \mathrm{~A}$ lack of commitment to preventive community-based dental health promotion might also be a factor. Prevention is still far from being appreciated within the community. 
The Indonesian government has demonstrated its willingness to improve the nation's dental health by committing itself to the establishment of a universal health-care coverage system. However, it is also time to evaluate dental health programs that emphasize prevention.

Dental caries comprise one of the most prevalent infectious diseases in Indonesia. ${ }^{3}$ Moreover, the unmet need for dental care is relatively high and is concentrated within the lower socioeconomic strata. ${ }^{4}$ A recent study revealed that $72 \%$ of elderly individuals who lived in Jakarta had missing teeth without prosthetic replacement. ${ }^{5}$ It can thus be established that Indonesia faces a high demand for providing dental health care programs to improve its citizens' dental health.

Very little information exists in the literature regarding tooth brushing behavior among Indonesians. As the capital city of Indonesia, Jakarta has a heterogeneous population hailing from numerous ethnicities and socioeconomic strata. This city could be considered as representative of the Indonesian population, and conducting a dental health study in Jakarta would likely represent Indonesia's dental health status. Epidemiological study of tooth brushing is essential to evaluate dental health. In essence, proper tooth brushing practice involve brushing teeth twice a day i.e. in the morning and at night, for at least two minutes each. However, this elementary behavior is not as widely and fully practiced as dentists and health organizations would like it to be, in order to achieve a basic health status worldwide. ${ }^{6,7}$ The aim of this study was to obtain data on tooth brushing frequency, time of day and duration in adults and children in Jakarta, Indonesia. This information will be used to design and evaluate behavior change programs in Indonesia to improve the country's dental health.

\section{METHODS}

Informed consent was obtained from each participant in the study. This study was conducted in compliance with the Declaration of Helsinki, principles of Good Clinical Practice and in accordance with applicable local laws. Ethical clearance was obtained from the Ethics Committee of the Faculty of Dentistry, University of Indonesia. One hundred and twenty families from various socioeconomic backgrounds and districts in Jakarta were randomly recruited for the study. The families were each composed of a father, mother and 2 children aged between 6 and 15 years, living in the same household. Families whose members had medical conditions that prevented them from brushing their teeth and those who shared toothbrushes were excluded.

All members of each family received a specially adapted toothbrush with a universal data logger inserted into the toothbrush handle. These loggers were deployed for a period of two weeks to record the frequency, time of day and duration for which subjects brushed their teeth. The families were instructed to use only the specially designed toothbrushes they were given for the study and to brush in their normal way at home. In addition, the existing toothbrushes were collected to prevent their use during the study period. The subjects used the provided toothbrush as part of their normal dental hygiene. Subjects were also instructed to use their normal toothpaste at home. Families were not told about the data logger located in the toothbrush until after the study completion. Once the study was complete, the families were asked to give permission for their data logger to be analyzed. After permission was granted, the data from the loggers were downloaded and used to calculate the tooth brushing frequency, time of day and duration for each individual.

\section{RESULTS}

Professional recommendations for individual dental hygiene mostly include tooth brushing at least twice daily, i.e. after breakfast and right before going to bed at night, for 2-3 minutes each. ${ }^{8}$ This study evaluated whether habitual tooth brushing actually meets these standards. Uninstructed adults $(n=240)$ and their children $(n=240)$ with habitual manual tooth brushing were given toothbrushes that recorded their brushing frequency, time and duration.

This study showed that only $12 \%$ of the population brushed their teeth twice daily, only $2 \%$ brushed their teeth for more than 2 minutes, and the majority of the tooth brushing (46\%) was performed in the morning (Table 1). The mean brushing frequency of the population was 1.27 times per day and the mean tooth brushing duration of this population was 57.29 seconds (Table 2). When appropriate brushing habits were defined as brushing at least twice daily for 120 seconds, none of the participants fulfilled all of the criteria, thus emphasizing the ongoing need for dental hygiene education and intervention.

The study revealed that mean daily tooth brushing frequency in the study population was below the recommended twice per day, and the frequency was in fact much closer to once per day. The mothers' tooth brushing frequencies tended to be higher than that of the other family members, and the fathers tended to brush their teeth longer (Table 3).

\section{DISCUSSION}

Tooth-brushing duration is an important variable for plaque removal efficacy. ${ }^{9}$ This study revealed that the brushing duration among the study population is still inadequate compared with other reported studies. ${ }^{10}$ Moreover, evidence supports the recommendation 
Table 1. Descriptive statistics children's gender, toothbrushing per day and toothbrushing time

\begin{tabular}{lr}
\hline Variable & Percentage \\
\hline Children's gender & \\
Male & $49.1 \%$ \\
Female & $50.9 \%$ \\
Toothbrushing per day & \\
$\quad$ Once a day & $37.2 \%$ \\
$\quad$ Sometimes once, sometimes twice & $50.9 \%$ \\
$\quad$ Twice a day & $12.0 \%$ \\
Toothbrushing duration & \\
$<60$ seconds & $64.3 \%$ \\
between 60 and 120 seconds & $33.7 \%$ \\
$>120$ seconds & $2.0 \%$ \\
Toothbrushing time & \\
4 am - $10 \mathrm{am}$ & $46.0 \%$ \\
$10 \mathrm{am}-3 \mathrm{pm}$ & $11.8 \%$ \\
$3 \mathrm{pm}-8 \mathrm{pm}$ & $30.0 \%$ \\
$8 \mathrm{pm}-4 \mathrm{am}$ & $12.2 \%$ \\
\hline
\end{tabular}

Table 2. Mean tooth brushing frequency and duration

\begin{tabular}{lcccc}
\hline Family Member & \multicolumn{2}{c}{$\begin{array}{c}\text { Mean } \\
\text { Frequency per } \\
\text { Day (95\% CI) }\end{array}$} & $\begin{array}{l}\text { Mean Duration in } \\
\text { Seconds (95\% CI) }\end{array}$ \\
\hline Father & 1.35 & $1.24-1.47$ & 71.01 & $65.63-76.39$ \\
Mother & 1.57 & $1.46-1.67$ & 62.00 & $57.61-66.39$ \\
Eldest Child & 1.10 & $0.98-1.22$ & 51.19 & $47.02-55.36$ \\
Youngest Child & 1.06 & $0.94-1.19$ & 44.35 & $41.54-47.17$ \\
Overall Mean & \multicolumn{2}{c}{1.27} & \multicolumn{2}{c}{57.29} \\
\hline
\end{tabular}

Table 3. Significance of toothbrushing frequency per day and toothbrushing duration between family members

\begin{tabular}{lllllll}
\hline \multicolumn{3}{c}{ Frequency } & \multicolumn{3}{l}{ Duration } \\
\hline \multicolumn{4}{c}{ Mother Eldest Youngest } \\
Child & \multicolumn{2}{c}{ Child } & & \multicolumn{2}{c}{$\begin{array}{c}\text { Eldest } \\
\text { Child }\end{array}$} & $\begin{array}{c}\text { Youngest } \\
\text { Child }\end{array}$ \\
Father & 0.052 & 0.012 & 0.003 & 0.014 & 0.000 & 0.000 \\
Mother & 0.000 & 0.000 & & 0.000 & 0.000 \\
Eldest & & 0.973 & & & 0.070 \\
Child & & & & & \\
\hline
\end{tabular}

that tooth brushing with fluoride toothpaste should be practiced prior to going to bed. Salivary flow rates decrease during sleep, and the resultant reduction in buffering capacity increases the risk of caries. ${ }^{11}$ However, the results of this study show that majority of the study population performs tooth brushing only early in the morning. This phenomenon could be explained by the fact that almost $90 \%$ of the Indonesian population is Muslim and therefore pray in the morning. Tooth brushing might be a habit before commencing morning prayers.

The population in this study tended to brush their teeth only once daily. This frequency is below the recommended tooth brushing frequency and even below the frequency reported from other countries where majority of the population, in all age groups, brush their teeth twice a day or more often. ${ }^{12,13}$ There is a great potential for improvement in tooth brushing habits, especially among children in Indonesia. Clinical trials have reported an association between brushing frequency and caries incidence. The caries incidence in subjects who brushed once a day was higher compared to those who brushed twice a day. ${ }^{14}$ While these data should be interpreted with some caution because of the association between brushing frequency and other health indicators such as social class and sugar consumption, it seems appropriate to recommend brushing twice daily. Such behavior sustains elevated concentrations of fluoride in plaque where it can inhibit dissolution of tooth mineral by acid..$^{15}$

Brushing twice a day has been reported to significantly decreases the prevalence of caries compared to brushing only once per day. ${ }^{16}$ Similar beneficial effects of brushing twice daily have also been found in terms of gingival health. ${ }^{17}$ Despite this clear scientific evidence and the strong endorsement of twice daily brushing from the dental profession through bodies such as the WHO, the FDI and dental associations, significant population segments still only brush their teeth once a day. ${ }^{18}$ Promoting twice daily brushing has received new impetus through the application of modern behavioral change theories. ${ }^{19}$ Based on these initiatives, dental health promotion programs have been developed using a range of tools and communication media. Effective programming and evaluations in shifting tooth brushing frequency from once to twice a day are urgently required in Indonesia.

Frequency, time and duration of tooth brushing should be emphasized more in dental health education, especially in Indonesia. Systematic reviews reveal good evidence to show that brushing twice a day with a fluoride toothpaste is effective in preventing dental caries and that this brushing regimen also prevents gingivitis and periodontal breakdown. Moreover, cost effectiveness of good tooth brushing behavior for dental caries prevention has previously been proven. ${ }^{20-22}$ We conclude that dental public health improvements remain a fundamental need in Indonesia and that there is an opportunity to address this need through changes in tooth brushing behavior.

This study performed in Jakarta, Indonesia, revealed that mean daily tooth brushing frequency in the study population of 120 families was below the recommended twice per day and below the recommended duration of 120 seconds. It is therefore necessary for all dental and general health practitioners, public health workers and the oral care industry to address this issue together and to reach out to those who do not normally seek oral health care to help them brush effectively twice a day.

\section{ACKNOWLEDGMENT}

Support of Unilever Research and Development Port Sunlight and PT Riset Prima Indonesia in the field study is greatly appreciated. 


\section{CONFLICT OF INTEREST}

The authors declare no conflict of interest.

\section{REFERENCES}

1. Maharani DA. Do the Indonesians receive the dental care treatment they need? A secondary analysis on self-perceived dental care need. ISRN Dent. 2012;769809, doi: 10.5402/2012/769809.

2. Maharani DA, Rahardjo A. Is the utilization of dental care based on need or socioeconomic status? A study of dental care in Indonesia from 1999 to 2009. Int Dent J. 2012;62:90-4.

3. Maharani DA. Inequity in dental care utilization in the Indonesian population with a self-assessed need for dental treatment. Tohoku J Exp Med. 2009;218:229-39.

4. Maharani DA. Perceived need for and utilization of dental care in Indonesia in 2006 and 2007: a secondary analysis. J Oral Sci. 2009;51:545-50.

5. Adiatman M, Ueno M, Ohnuki M, Hakuta C, Shinada K, Kawaguchi Y. Functional tooth units and nutritional status of older people in care homes in Indonesia. Gerodontology. 2013;30:262-9.

6. Claessen JP, Bates S, Sherlock K, Seeparsand F, Wright R. Designing interventions to improve tooth brushing. Int Dent J. 2008;58:307-20.

7. Davies RM, Davies GM, Ellwood RP, Kay EJ. Prevention. Part 4: Toothbrushing: What advice should be given to patients? Br Dent J. 2003;195:13541.

8. Ganss C, Schlueter N, Preiss S, Klimek J. Tooth brushing habits in uninstructed adults - frequency, technique, duration and force. Clin Oral Investig. 2009;13:203-8.

9. Honkala E, Nyyssönen V, Knuuttila M, Markkanen H. Effectiveness of children's habitual toothbrushing. J Clin Periodontol. 1986;13:81-5.

10. Asadoorian J. Position Paper on Tooth Brushing. CJDH. 2006;40:232-48.

11. Davies RM, Ellwood RP, Davies GM. The rational use of fluoride toothpaste. Int J Dent Hygiene. 2003;1:3-8.
12. Jensen $O$, Gabre P, Sköld UM, Birkhed D. Is the use of fluoride toothpaste optimal? Knowledge, attitudes and behavior concerning fluoride toothpaste and tooth brushing in different age groups in Sweden. Community Dent Oral Epidemiol. 2012;40:175-84.

13. Sharma S, Yeluri R, Jain AA, Munshi AK. Effect of toothbrush grip on plaque removal during manual toothbrushing in children. J Oral Sci. 2012;54:18390.

14. Chestnutt IG, Schäfer F, Jacobson APM, Stephen $\mathrm{KW}$. The influence of toothbrushing frequency and postbrushing rinsing on caries experience in a caries clinical trial. Community Dent Oral Epidemiol. 1998;26:406-11.

15. Featherstone JDB. The science and practice of caries prevention. J Am Dent Assoc. 2000;131:887-99.

16. Chesters RK, Huntington E, Burchell CK, Stephen KW. Effect of oral care habits on caries in adolescents. Caries Res. 1992;26:299-304.

17. Kolawole KA, Oziegbe EO, Bamise CT. Oral Hygiene measures and the periodontal status of school children. Int J Dent Hyg. 2011;9:143-8.

18. Schäfer F, Nicholson JA, Gerritsen N, Wright RL, Gillam DG, Hall C. The effect of oral care feed-back devices on plaque removal and attitudes towards oral care. Int Dent J. 2003;53:404-8.

19. Sniehotta FF, Soares VA, Dombrowski SU. Randomized controlled trial of a one-minute intervention changing oral self-care behavior. J Dent Res. 2007;86:641-5.

20. Eaton KA, Carlile MJ. Tooth brushing behavior in Europe: opportunities for dental public health. Int Dent J. 2008;58:287-93.

21. Poutanen R, Lahti S, Tolvanen M, Hausen H. Gender differences in child-related and parentrelated determinants of oral health-related lifestyle among 11- to 12-year-old Finnish schoolchildren. Acta Odontol Scand. 2007;65:194-200.

22. Poutanen R, Lahti S, Tolvanen M, Hausen H. Parental influence on children's oral health-related behavior. Acta Odontol Scand. 2006;64:286-92. 